\title{
Current status of urban wastewater treatment plants in China
}

\author{
Q.H. Zhang ${ }^{\mathrm{a}, \mathrm{b}, \star}$, W.N. Yang ${ }^{\mathrm{b}}$, H.H. Ngo ${ }^{\mathrm{c}, \star \star}$, W.S. Guo ${ }^{\mathrm{c}}$, P.K. Jin ${ }^{\mathrm{b}}$, Mawuli Dzakpasu ${ }^{\mathrm{b}}$, S.J. Yang ${ }^{\mathrm{a}}$, Q. Wang ${ }^{\mathrm{a}}$, \\ X.C. Wang ${ }^{a}$, D. Ao ${ }^{a}$
}

a Key Lab of Northwest Water Resource, Environment and Ecology, Ministry of Education, Xi'an University of Architecture and Technology, Xi'an 710055, China

' School of Environmental and Municipal Engineering, Xi'an University of Architecture and Technology, Xi'an 710055, China

' Centre for Technology in Water and Wastewater, School of Civil and Environmental Engineering, University of Technology, Sydney, PO Box 123, NSW 2007, Australia

*Correspondence to: Q.H. Zhang, Key Lab of Northwest Water Resource, Environment and Ecology, Ministry of Education, Xi'an University of Architecture and Technology, Xi'an 710055, China.

** Corresponding author

E-mail addresses: qionghuazhang@126.com (Q.H. Zhang), h.ngo@uts.edu.au (H.H. Ngo)

\begin{abstract}
The study reported and analyzed the current state of wastewater treatment plants (WWTPs) in urban China from the perspective of treatment technologies, pollutant removals, operating load and effluent discharge standards. By the end of 2013, 3508 WWTPs have been built in 31 provinces and cities in China with a total treatment ca- pacity of $1.48 \times 108 \mathrm{~m} 3 / \mathrm{d}$. The uneven population distribution between China's east and west regions has resulted in notably different economic development outcomes. The technologies mostly used in WWTPs are AAO and ox- idation ditch, which account for over $50 \%$ of the existing WWTPs. According to statistics, the efficiencies of COD and NH3-N removal are good in 656 WWTPs in 70 cities. The overall average COD removal is over $88 \%$ with few regional differences. The average removal efficiency of NH3-N is up to $80 \%$. Large differences exist between the operating loads applied in different WWTPs. The average operating loading rate is approximately $83 \%$, and $52 \%$ of WWTPs operate at loadings of b $80 \%$, treating up to $40 \%$ of the wastewater generated. The implementation of discharge standards has been low. Approximately 28\% of WWTPs that achieved the Grade I-A Discharge Stan- dard of Pollutants for Municipal Wastewater Treatment Plant (GB 18918-2002) were constructed after 2010. The sludge treatment and recycling rates are only $25 \%$, and approximately $15 \%$ of wastewater is inefficiently treated. Approximately $60 \%$ of WWTPs have capacities of $1 \times$ $104 \mathrm{~m} 3 / \mathrm{d}-5 \times 104 \mathrm{~m} 3 / \mathrm{d}$. Relatively high energy consumption is required for small-scale processing, and the utilization rate of recycled wastewater is low. The challenges of WWTPs are discussed with the aim of developing rational criteria and appropriate technologies for water recycling. Suggestions regarding potential technical and administrative measures are provided.
\end{abstract}

Keywords: Wastewater treatment plants (WWTPs); Regional sewage treatment; Discharge standard and upgrading Sludge disposal; Energy consumption; Wastewater reclamation and reuse

\section{Contents}

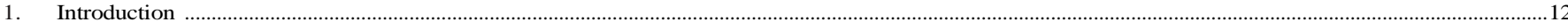

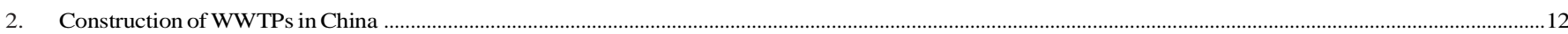

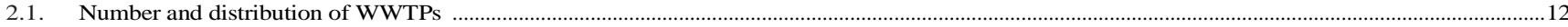

2.2. Scale of WWTPs

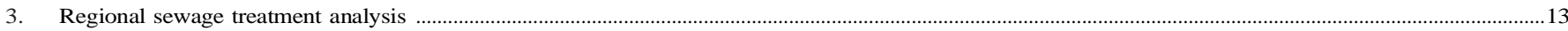

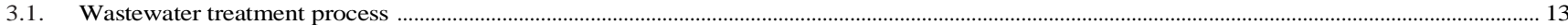

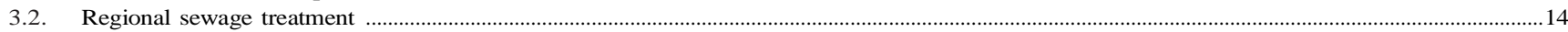

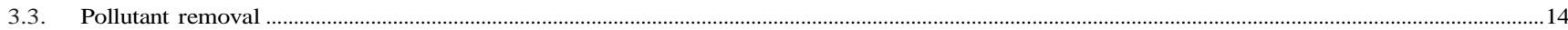

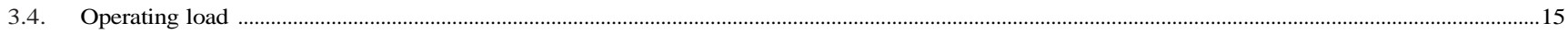

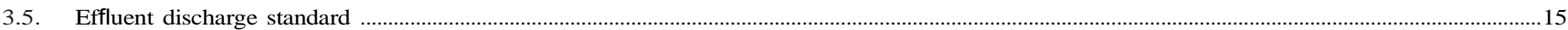

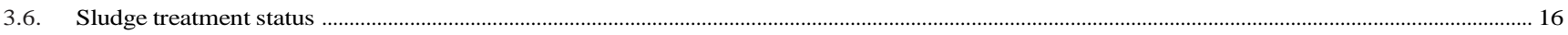

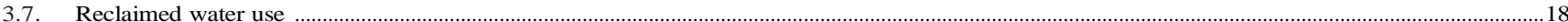

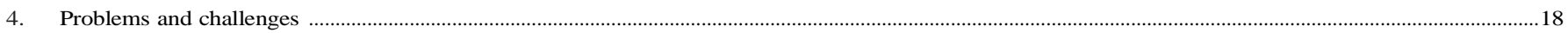

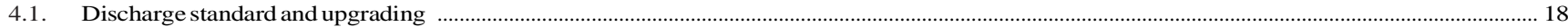




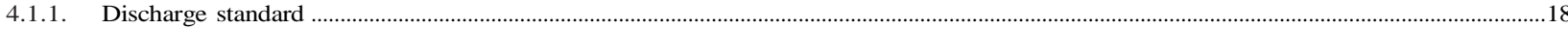

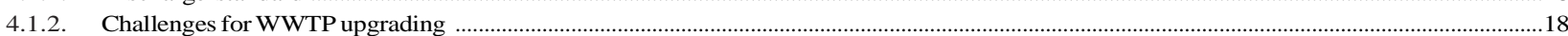

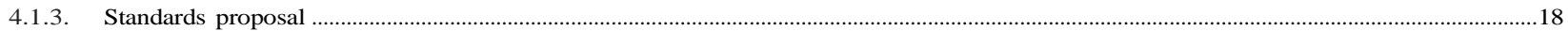

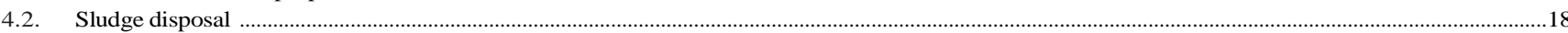

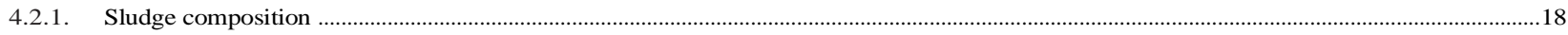

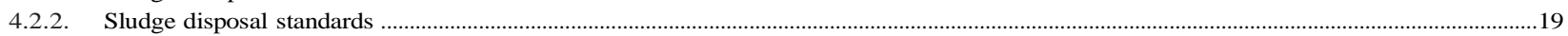

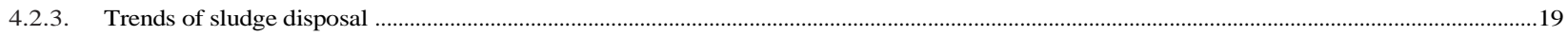

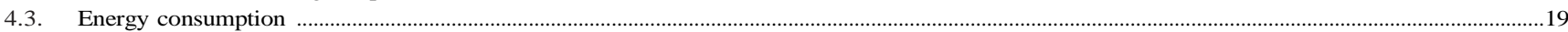

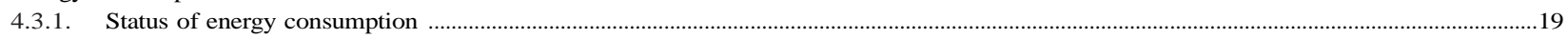

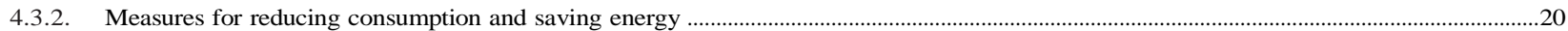

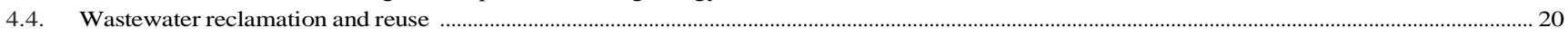

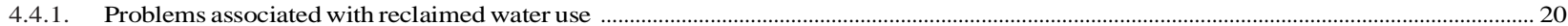

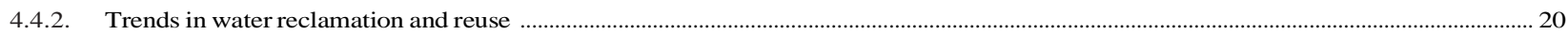

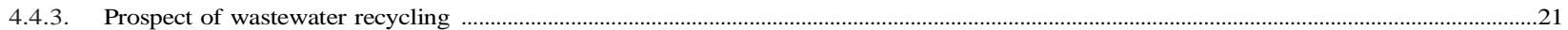

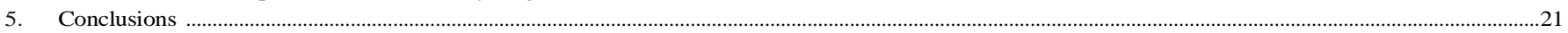

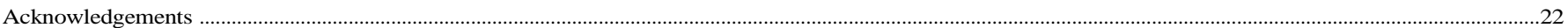

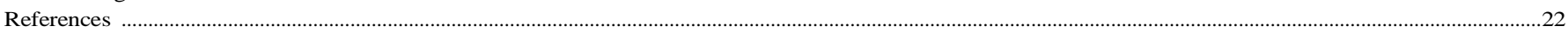

\section{Introduction}

Water scarcity poses a serious threat to the development of human societies. Wastewater reclamation and reuse is considered to be the best strategy for meeting current and future water needs. On the other hand, water pollution represents an especially dangerous problem in developing countries, such as China. In 2012, the total national wastewater discharge in China was 68.5 billion tons, which represented a $3.7 \%$ increase over the previous year. In 2013, 23.5 and 2.5 million tons of chemical oxygen demand (COD) and ammonia nitrogen, respectively, were discharged (China Environmental Status Bulletin, 2013). Thus, the need to analyze the achievements and future challenges of wastewater treatment in China cannot be overemphasized.

In recent years, as economic development has accelerated and public and governmental consciousness of environmental protection has grown, China's capacity to treat sewage has rapidly expanded. This capacity was established in a relatively short period, within which the treatment efficiencies were also significantly improved. The capacity and efficiency of wastewater treatment plants (WWTPs) have increased from $0.4 \times 10^{6} \mathrm{~m}^{3}$ and $14.9 \%$, respectively, in 1991 to $3.8 \times 10^{6} \mathrm{~m}^{3}$ and $89.3 \%$ in 2013, indicating rapid development of sewage treatment. Although China has established the second largest sewage treatment capacity in the world (after the United States), regional developments are largely imbalanced. For example, the sewage treatment efficiencies in Heilongjiang (60.8\%), Qinhai (60.4\%) and Tibet (0.06\%) are significantly less than the national average.

Wastewater treatment consists of primary, secondary, and sometimes advanced treatment processes, with different biological, physical, and chemical technologies. At present, many sewage treatment processes are used in WWTPs in China, including conventional activated sludge treatment, anaerobic-anoxic-oxic (A2/O), anaerobic-oxic (A/O), sequencing batch reactor (SBR), and oxidation ditch. The treatment efficiency of a WWTP is related to the process and also depends on the scale of the WWTP.

As of 2012, the six provinces or municipalities with per capita urban sewage discharges $\mathrm{N} 45 \mathrm{~m}^{3}$ were Shanghai, Beijing, Tianjin, Guangdong, Liaoning province, and Ningxia, in decreasing order. Shanghai, which had the highest per capita urban sewage discharge, ranked seventh for treatment efficiency, whereas Liaoning, which had the fifth highest per capita urban sewage discharge, ranked 22nd for treatment efficiency. Thus, the rankings of discharge and treatment efficiency of sewage and wastewater treatment facilities vary between regions. This variability depends on many factors, including the huge amount of the population (1.3 billion) in China, rapid economic growth, industrialization, urbanization and inadequate investment in infrastructure.

According to Yang et al. (2011), the construction of WWTPs and China's improved treatment capacity showed apparent geographical distribution, except in the northwest region, where capacity and GDP demonstrated good colinearity. A report by Yang et al. (2012) on the different treatment technologies for the utilization of sewage sludge showed an increasing trend in China. Due to the heterogeneous character of economic development, the eastern part of China showed higher increases, especially in Zhejiang and Jiangsu. Wang (2013) analyzed the investment, maintenance and annual operation costs of urban WWTPs; as an example, aeration equipment demonstrated a reasonable update lifetime of six years. However, it is difficult to maintain this frequency of updating equipment, which may explain why energy consumption is higher than that in developed countries. For this reason, Qu (2007) proposed the application of Public-Industry-Private-Partner (PIPP) investment and financing in WWTPs. However, governmental investment primarily funds the construction and operation of WWTPs, which has many disadvantages, such as construction delays, high expenses, and high energy consumption. These disadvantages consequently mean that WWTPs cannot achieve the required discharge standard.

Thus, the geographical distribution of WWTPs needs to be carefully and strategically considered, given that the rapid expansion of WWTP construction in China is almost complete. As such, there is a need to summarize and analyze the current situation in a focused document. Research on the state of sewage treatment in China is rarely reported. Therefore, this article reviews the current state of regional wastewater treatment in China. We focus on the treatment technologies, pollutants removals, operating load and effluent discharge standards. Furthermore, we provide an analysis of discharge standard and upgrading, sludge disposal, energy consumption, wastewater reclamation and reuse. The results of this review will provide effective technical support for the construction and operation of WWTPs.

\section{Construction of WWTPs in China}

\subsection{Number and distribution of WWTPs}

By the end of 2013, 3508 WWTPS had been built in 31 provinces. However, the distribution of WWTPS is dramatically uneven throughout China (Fig. 1). Of the 3508 WWTPs, 383 are located in Guangdong province, and 366 are in Jiangsu province, which are at the top of the list. Furthermore, 221 WWTPs are situated in Shandong province. In 19 provinces, the number of WWTPs is over 100, accounting for $61.3 \%$ of the total, with 118 in Liaoning, 114 in Guangxi, 111 in Shaanxi, 109 in Anhui, 108 in Inner Mongolia, 106 in Xinjiang, 101 in Jiangxi and Guizhou and 99 in Fujian. For the remaining 12 provinces, the number of WWTPs is $\mathrm{b} 100$. Of these, Xizang, Qinghai and Tianjin are at the bottom, with 2, 18 and 24, respectively. 


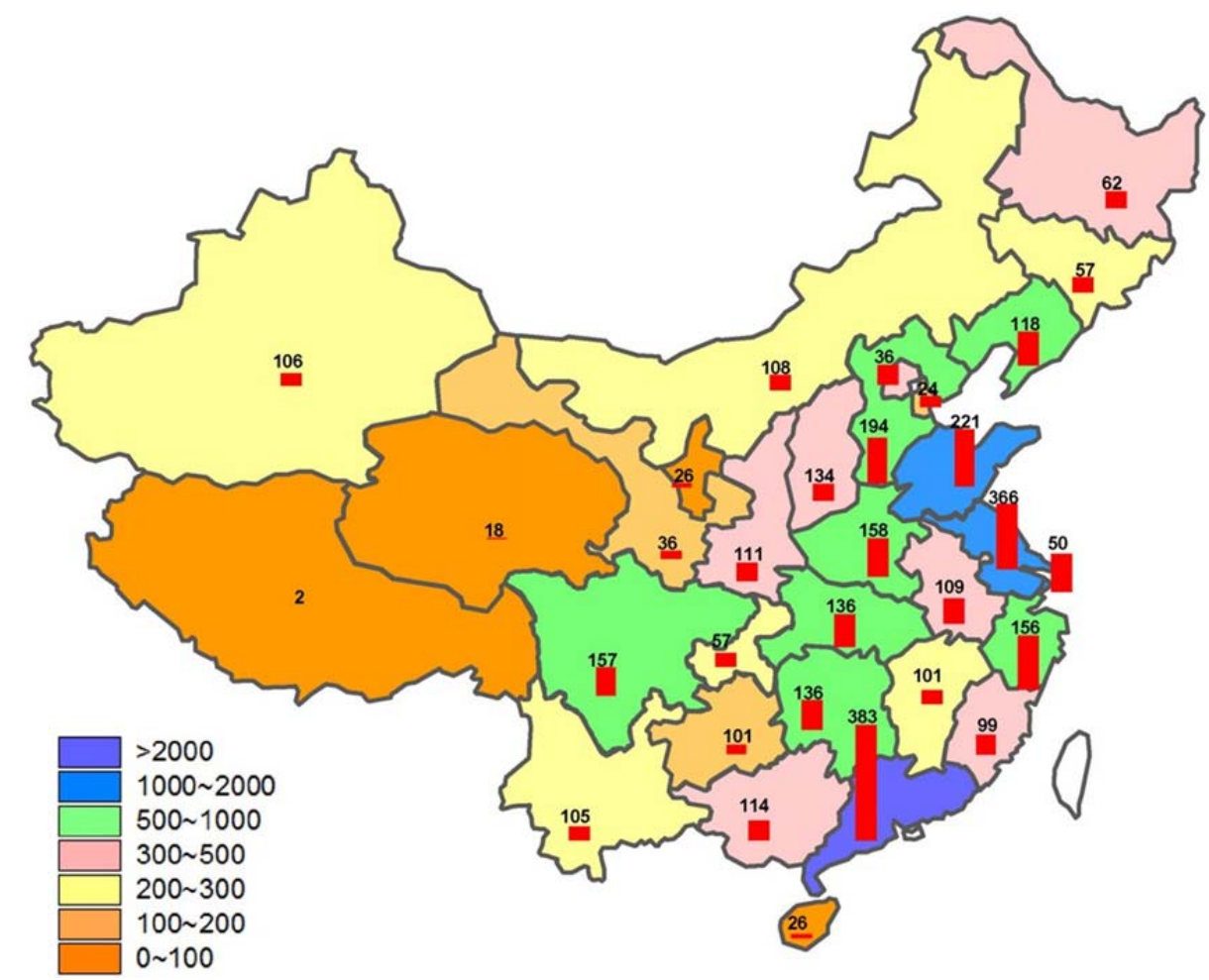

Fig. 1. Distribution of WWTPs in China.

\subsection{Scale of WWTPs}

By the end of 2013, the capacities of the 3508 WWTPs added up to $1,4758,000$ t/d. Fig. 1 shows that the treatment capacities of WWTPs vary greatly by province, wherein Guangdong is ahead of the other provinces, with a capacity of over 20 million $t / d$. The next two provinces with the highest capacities are Jiangsu and Shandong, with $12,440,000 \mathrm{t} / \mathrm{d}$ and $10,780,000 \mathrm{t} / \mathrm{d}$, respectively. The capacity of the plants in the first three provinces accounts for $30 \%$ of the total. Of the remaining provinces, 11 can treat wastewater of over 5 million $t / d$, accounting for $30 \%$ of the total capacity in China. The four provinces with capacities b 1000.000 t/d are Hainan, Ningxia Hui Autonomous, Qinghai, and Tibet. Of these four, Tibet lags well behind the others, with a capacity of 59,000 $\mathrm{m}^{3} / \mathrm{d}$. Overall, the WWTPs with smaller capacities to treat wastewater are mainly distributed in the west and northwest, where the total capacities of Qinghai, Ningxia, Gansu, Xinjiang, Xizang and Inner Mongolia are a mere $296 \mathrm{~m}^{3} / \mathrm{d}$, accounting for $5 \%$ of the total capacity in China.

\section{Regional sewage treatment analysis}

3.1. Wastewater treatment process

a. Distribution of the number of different processes; b. Distribution of the scale of different process.
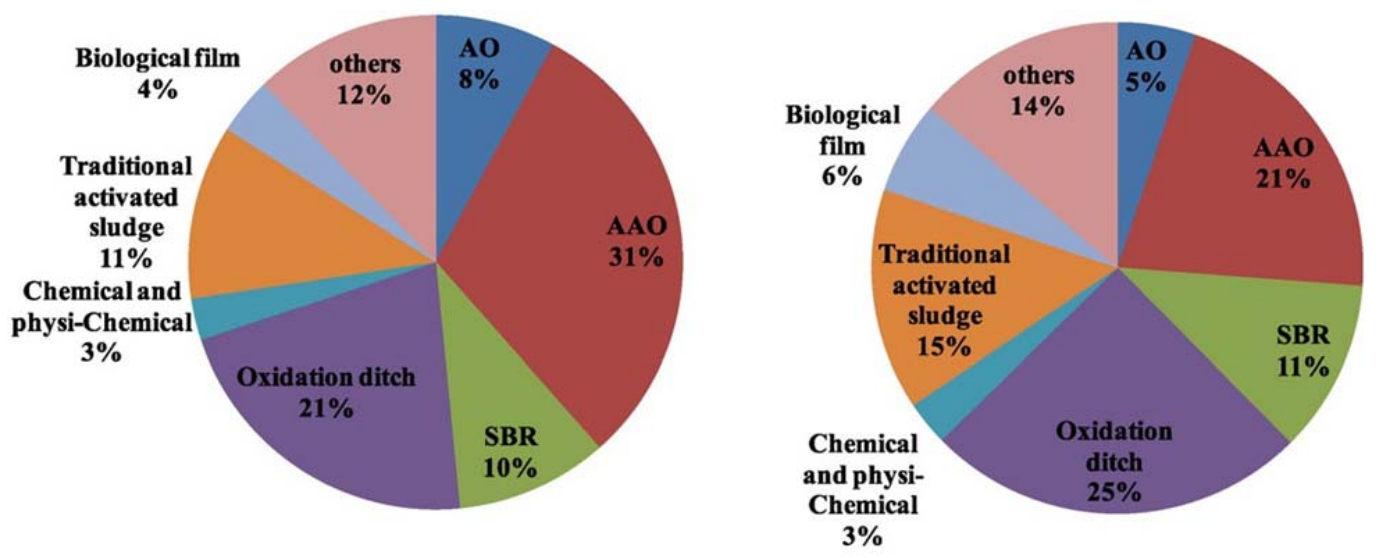

\section{a. distribution of the number in different process}

\section{b. distribution of the scale in different process}

Fig. 2. Comparison of wastewater treatment processes in China. 
The most widely used wastewater treatment processes are AAO and oxidation ditch, which have been adopted in over $50 \%$ of the WWTPs (Fig. 2). Of all the technologies, AAO has been adopted in $31 \%$ of WWTPs, whereas oxidation ditch has been used in $21 \%$ of them. The traditional activated sludge and SBR account for $11 \%$ and $10 \%$ of the total number of WWTPs, respectively. The others, including AO, biological film, chemical and physicochemical, account for $27 \%$.

Overall, approximately $50 \%$ of wastewater treatment processes are oxidation and AAO, which treat $46 \%$ of the total volume of wastewater generated. One quarter of the wastewater is treated by traditional activated sludge and SBR, and $28 \%$ is treated by other processes (AO, biological film, chemical and physicochemical among others). As described above, AAO and oxidation ditch are the major processes employed in China. These two technologies are often chosen for their craft and capability and because they are relatively stable and easy to manage in daily operations.

\subsection{Regional sewage treatment}

Mainland China can be divided into seven regions, namely Northeast area, North China, East China, Central China, South China, Northwest area and Southwest area as demonstrated in Fig. 3.

Fig. 3 shows the number and scale of WWTPs in these seven areas and also illustrates the land area of the respective regions and their populations.

The construction of WWTPs and their treatment capacities show clear, significant variations in regional distribution; sewage treatment levels and status vary considerably from region to region. In East China, only $6.5 \%$ of the total land area in China. The number of WWTPs accounts for $30 \%$ of the total, and the capacity is close to $1 / 3$. By contrast, in the Northwest, where the land area is five times that of East China, the sewage treatment scale is the smallest and is merely 1/ 6 of the scale of East China. This difference is mainly caused by the uneven population distribution and unbalanced economic development in the two regions. In terms of $\mathrm{S} / \mathrm{P}\left(10^{4} \mathrm{t} /\left(\mathrm{d} \cdot 10^{4} \mathrm{P}\right)\right)$, China's average level is $0.12\left(10^{4} \mathrm{t} /\left(\mathrm{d} \cdot 10^{4} \mathrm{P}\right)\right)$. The magnitude in the seven regions in descending order is as follows: South China, East China, North China, Northeast area, Northwest area, Central China, and Southwest area. In the Northeast area, the S/P $\left(10^{4} \mathrm{t} /\left(\mathrm{d} \cdot 10^{4} \mathrm{P}\right)\right)$ has reached 0.11 $\left(10^{4} \mathrm{t} /\left(\mathrm{d} \cdot 10^{4} \mathrm{P}\right)\right)$, which is close to the average level in China. In South China, the sewage treatment capacity per 10 thousand persons is 2.5 times that of the Southwest area.

\subsection{Pollutant removal}

The removal efficiencies of COD and $\mathrm{NH}_{3}-\mathrm{N}$ in 656 WWTPs in 70 cities are presented in Fig. 4. The average removal rates in the seven regions show little difference, which is generally up to $88 \%$, except for a few individual cities. In addition, the COD concentrations in all WWTPs meet the requirements of the first grade A standard. Compared to the statistics in the international literature, the removal of COD in China is as good as that of the WWTPs in developed countries. The main reason for this similarity is because China mainly adopts traditional activated sludge and mutational technologies. Of the two, the former is good in dealing with COD.

The average $\mathrm{NH}_{3}-\mathrm{N}$ removal rate is approximately $80 \%$, although considerable variation can be observed in the seven regions, with those in Northwest, Northeast China and North China falling below the national level. Several cities have even lower removals of b50\% along with poor decant conditions. For example, in Urumchi (Northwest) the $\mathrm{NH}_{3}-\mathrm{N}$ removal efficiency is only $27.7 \%$, whereas in Shenyang (Northeast Region) and Baotou (North China), the removal efficiencies are $45.6 \%$ and $37.4 \%$, respectively. The reasons for these differences are obsolete sewage treatment equipment in the northern cities and temperature, which is one of the most critical factors in the sewage treatment process. The average temperature of the northern cities is $5-8^{\circ} \mathrm{C}$, which is lower than that of the southern cities, and the low temperature period in the northern cities lasts longer than in the southern ones.

However, almost $90 \%$ of WWTPs in China have problems with nutrient removal, especially total nitrogen. Approximately 50\% of WWTPs do not meet the nitrogen discharge standard.

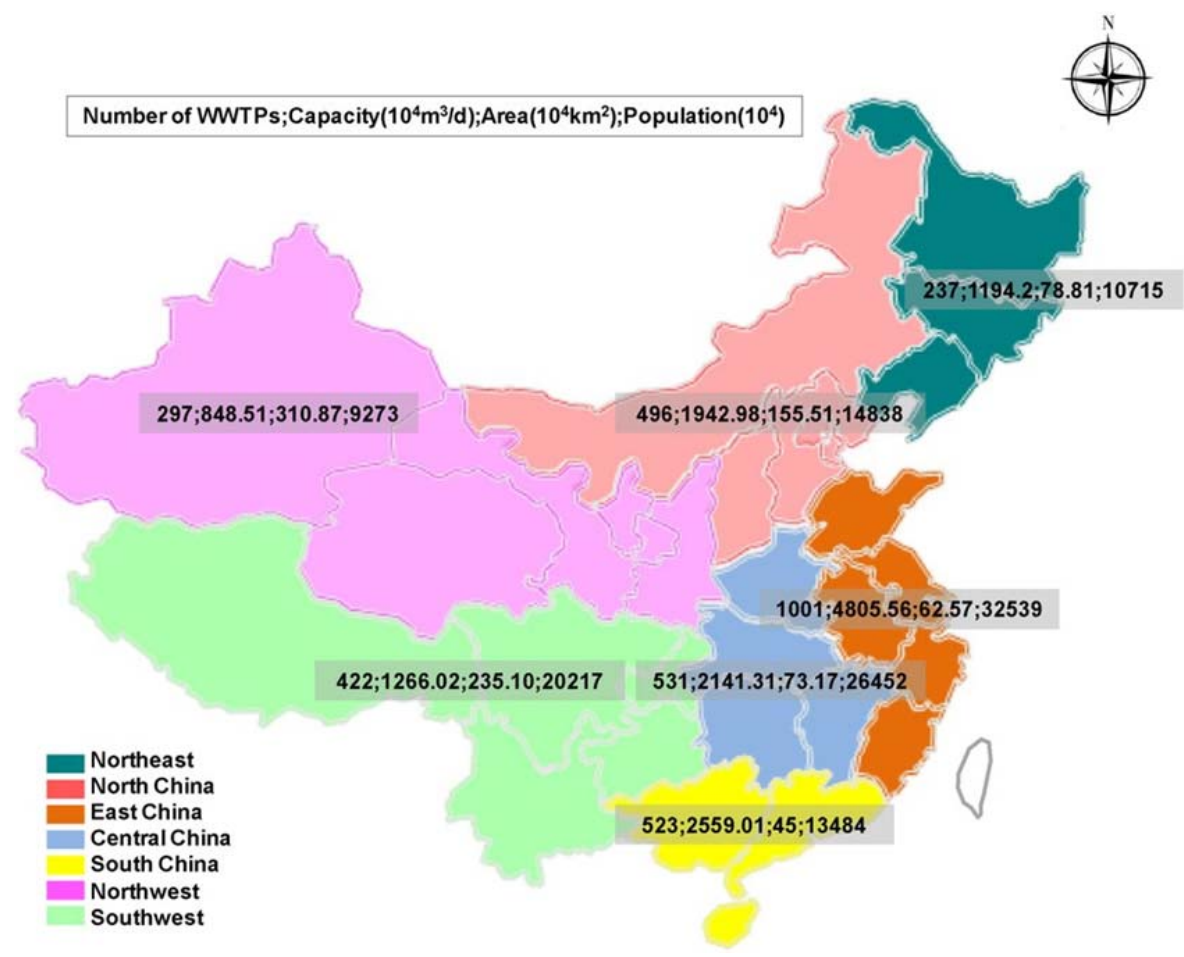

Fig. 3. Status of regional sewage treatment in China. 


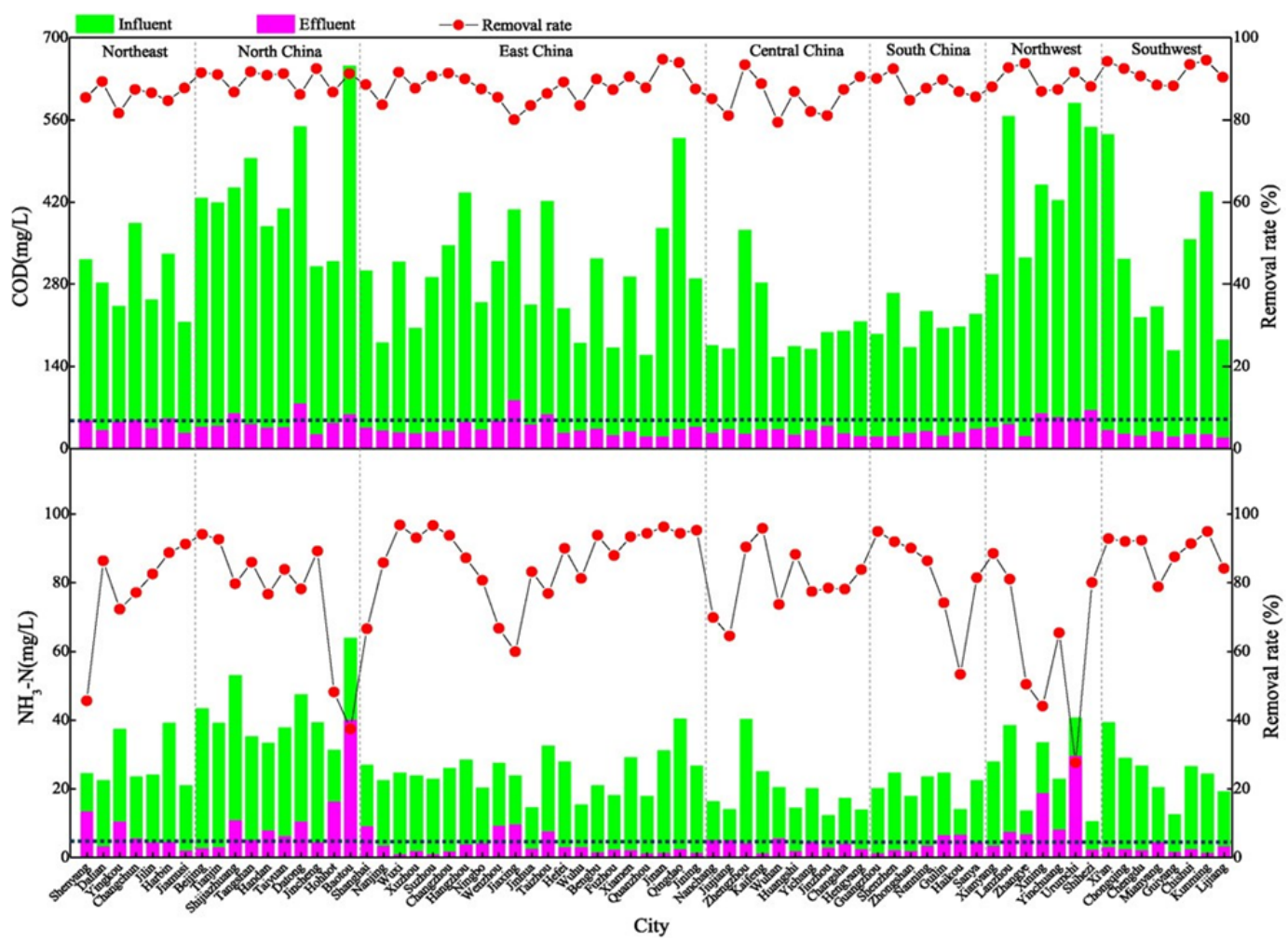

Fig. 4. The removal of COD and NH3-N in 656 WWTPs in 70 cities.

\subsection{Operating load}

The operating loads of the 656 sewage treatment plants (Fig. 5) vary greatly, with an average operating load rate of approximately $83 \%$. In general, the operating load of $52 \%$ of the WWTPs is $b 80 \%$, and the total treated water is $40 \%$. The long-term low operating load increases the energy consumed in the treatment process. Additionally, only $30 \%$ of the WWTPs have operating loads of $80-100 \%$, with nearly $40 \%$ of the wastewater being treated. The operating loads in $18 \%$ of the WWTPs exceed $100 \%$, and $22 \%$ of the wastewater is overloaded. Moreover, the operating loads in $2 \%$ of the WWTPs are over $120 \%$. Overloading of the operation affects wastewater treatment performance to a large extent, especially in terms of removing $\mathrm{N}$ and $\mathrm{P}$ and other pollutants.

The overall operation loading rate in the seven regions varies considerably, of which the East, Central, and Southwest have the highest rates of over $85 \%$.Nonetheless, the rate is b $90 \%$. Furthermore, the rate in the Northwest is only $74 \%$, which is also the most delayed region in terms of economic development.

\subsection{Effluent discharge standard}

Fig. 6 shows the discharge quality of the 656 WWTPs in the seven regions. A huge challenge that requires focus is that only 185 WWTPs

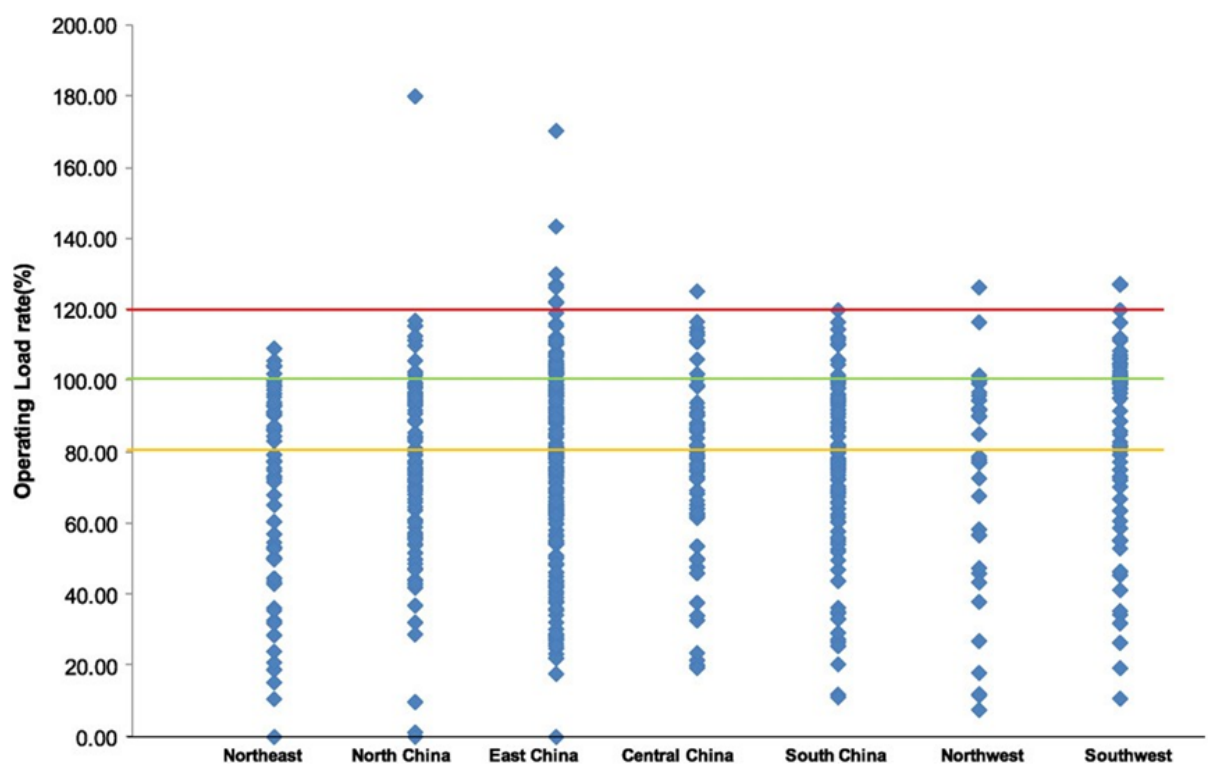

Fig. 5. Regional sewage treatment operating load in China. 

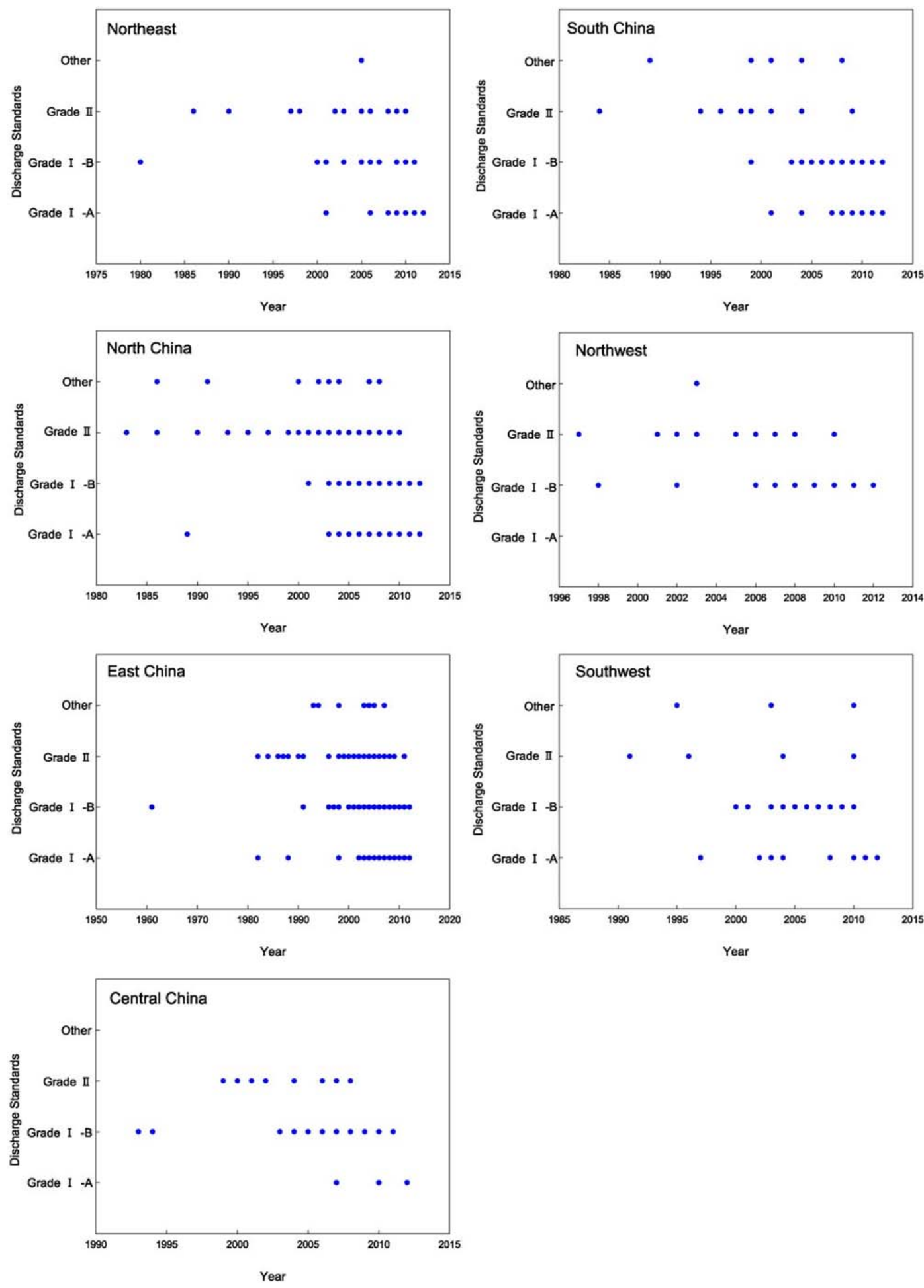

Fig. 6. Effluent discharge standard of WWTP in China.

(approximately 28\% of WWTPs) achieved the Grade I-A Discharge Standard of Pollutants for Municipal Wastewater Treatment Plant (GB 18918-2002), and these were mainly constructed after 2010. Approximately 282 WWTPs (43\%) achieved the Grade I-B Discharge Standard, and almost 30\% do not meet the Grade I-B standard.

The WWTPs in East China achieved the Grade I-A standard in 2000. Nearly $80 \%$ of WWTPs achieved the Grade I-A standard, especially in Jiangsu, Zhejiang, Shanghai and other economically developed regions. The WWTPs in Guangzhou of South China achieved the Grade I-A discharge standard in 2005. The WWTPs in the Northeast and North areas have achieved the lowest rate of Grade I-A, whereby 34 WWTPs in the Northwest were below Grade I-A. Differences in economic development are clearly related to the implementation of standards.

\subsection{Sludge treatment status}

Although most WWTPs in China are equipped with sludge treatment facilities, N80\% of sludge is improperly treated. Sludge treatment involves dewatering and stabilization processes (Jin et al., 2014; Yang et al., 2015a). The sludge treatment in most Chinese WWTPs is basically 
a "thickening-coagulation-mechanical dewatering" process (Yang et al., 2015a).

Currently, WWTPs produce more than six million tons of sludge (dry matter basis), which is equivalent to over 3000 tons of sludge containing $80 \%$ moisture. Consequently, the sludge outlet has become one of the major bottlenecks restricting the healthy development of wastewater treatment (Yang et al., 2015a). Fig. 7 shows the status of sludge treatment in 656 WWTPs in 70 cities in 7 regions of China, which vary greatly in terms of the method of sludge treatment. Overall, the rates of sludge landfilling, combustion, recycling of materials, and composting are $50 \%$, $10 \%, 9 \%$, and $16 \%$, respectively. The proportion of resource recycling (recycled building materials, compost) is only $25 \%$, whereas untreated sludge takes up $15 \%$. As in Japan, sludge disposal in open dumps is no longer allowed in China.

In the Northeast, landfilling is the main treatment method, with sludge combustion and building material utilization ratios being very low. In Shenyang, b $1 \%$ of sludge is treated by combustion. In Harbin, a mere $2 \%$ of sludge is reutilized for building materials. In Dalian and Harbin, the proportion of sludge that is ineffectively treated in the municipal sewage treatment plants remains high. The overall recovery rate of sludge resources (compost, building material utilization) is $11.6 \%$.

In North China, excluding Beijing, the sludge landfilling rate is b $20 \%$. However, the average rate of urban landfilling is N75\%, which is the main approach to treating sludge. In Handan, the sludge landfilling rate is up to $96 \%$, and the remaining $4 \%$ of sludge is not effectively treated. The proportion of sludge utilization for building materials is rather high in Beijing and Datong, at approximately $21 \%$ and $11 \%$, respectively. However, in the other cities of North China, the utilization of sludge for building materials is zero. Sludge incineration in Beijing and Tianjin can be up to $5.3 \%$ and $1.4 \%$, respectively, whereas the sludge incineration rate in Shijiazhuang, Datong, Taiyuan, Hohhot, and Tangshan is very low or even zero. This low level of incineration is influenced by the government's tightly controlled incineration policy, which is linked to the poor air quality in these traditional industrial cities. Overall, in North China, using sludge as a resource is $26 \%$, which is almost equal to the national level. Nonetheless, $25 \%$ of sludge is not effectively treated, which is far below the national average.

In East China, sludge is largely treated by landfilling and incineration, whereby the overall sludge treatment rate of $89 \%$ is higher than that of other regions. The sludge landfilling rate of $31 \%$ is higher than that in the other cities, and it is $\mathrm{N} 75 \%$ in Jinhua, Wenzhou, Fuzhou, and Shanghai at $96.2 \%, 84.4 \%, 78.6 \%$ and $76.3 \%$, respectively. Comparatively, in Xuzhou, Jiaxing, Wuhu and other cities, incineration is the main technology used in the WWTPs, with basically no landfilling. These have an incineration rate of over $80 \%$, which is the highest in China. In Wuxi city, approximately $60 \%$ of sludge is used as a building material, which is the highest utilization rate in East China. However, the building material utilization rate is almost zero in Ningbo, Jinhua, Taizhou, Bengbu, Fuzhou, Quanzhou, Jinan, Qingdao and other cities. In Jinan, N90\% of sludge is composted. In East China, up to $11 \%$ of sludge is not effectively treated. For example, in Nanjing, Jiangsu, Suzhou, Changzhou and other developed areas, approximately $3 \%$ of sludge is not efficiently treated. These cities have taken the lead in the experiment of standard A transformation and sludge recycling in WWTPs.

In Central China, the sludge landfilling rate is extremely high, with an average of $81 \%$. For the WWTPs in Kaifeng, Wuhan, Changsha and Hengyang, the sludge landfilling rate is N95\%. On the other hand, of the ten cities counted, $3 \%$ incinerate sludge, with Yichang being the only city having an incineration rate of over 50\%; Jiujiang has a rate of $40 \%$, Nanchang $24 \%$, Huangshi $12 \%$, and the remaining six cities do not incinerate sludge. The rate of sludge utilization for building materials is $30 \%$ in Nanchang. The other cities do not implement this technology. The rate of composting is only $27 \%$ in Zhengzhou and zero in the other cities. Overall, $3 \%$ of sludge is not effectively disposed of, which can be as high as $43 \%$ in Jingzhou, far higher than the national average.

In South China, the sludge landfilling ratio exceeds $50 \%$ in the WWTPs examined, which are mainly distributed in Shenzhen, Zhongshan and Guangzhou. The sludge incineration rate is the lowest at only $1 \%$, and $2 \%$ of the sludge is incinerated in two cities, Shenzhen and Zhongshan. The utilization of sludge for building material is primarily employed in Guangzhou (25\%) and Nanning (10\%), whereas composting is mainly applied in Guilin, Haikou and Sanya. Up to $90 \%$ of sludge is untreated in Nanning city, which is the highest rate among all the cities counted. The rate in Zhongshan is close to $1 / 3$, but this varies considerably in the other cities.

In the cities of the Northwest, up $71 \%$ of the sludge is landfilled, and approximately $10 \%$ is composted. There is no sludge incineration and utilization for building material. Overall, approximately $20 \%$ of sludge is not effectively treated. However, this amount is up to $72 \%$ in Xianyang, 27\% in Xi'an, and 23\% in Xining. Landfilling is the main technology used in Urumqi and Shihezi, with N95\% of the sludge treated this way. In Yinchuan, almost all sludge is composted.

In the Southwest, sludge is also disposed of by bringing it to the landfill, the rate of which is as high as $84 \%$. Except for Mianyang, which has a lower rate, the landfilling rate in Chongqing is close to $2 / 3$. The remaining cities have higher rates of N90\%. In Mianyang, all the WWTPs dispose of sludge by using it for building materials. In total, the rates of incineration and composting are only $2 \%$ in the Southeast. Overall, the rate of sludge resource utilization in the Southwest is the lowest and

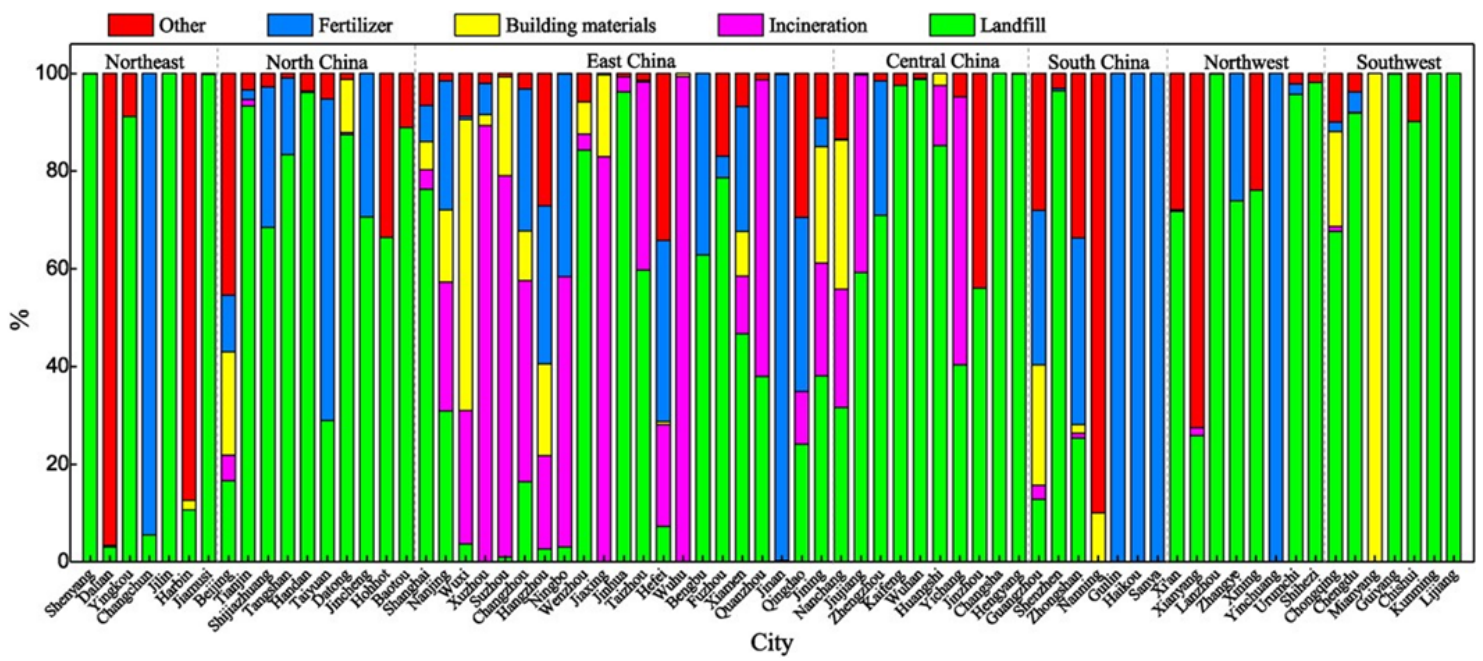

Fig. 7. Sludge treatment and disposal in 656 WWTPs in 70 cities in 7 regions of China. 
is under huge pressure in terms of sludge disposal, although there remains large potential.

Sludge disposal is an expensive operation, which can cause significant environmental pollution if dealt with improperly (Feng et al., 2015; Liu et al., 2014; Yang et al., 2015a; Zeng et al., 2012, 2014). At present, sanitary landfilling remains the major disposal method in China, with sludge incineration and land application having few applications (Yang et al., 2015a; Zeng et al., 2014).

\subsection{Reclaimed water use}

Water for urban regeneration accounts for only $14 \%$ of total urban sewage treatment, while the rate of reclaimed water use is nearly $60 \%$ (China Urban Construction Statistics Yearbook, 2014). However, the reclaimed water use is only $8.4 \%$ of the total amount of urban sewage treatment in 2013. This rate is lower than that of developed countries in Europe and America and is thus inadequate for the current situation of water resource scarcity in China. In the majority of water scarce areas, especially Shaanxi, Gansu, Qinghai and other regions, the quantity of reclaimed water and the reuse rate are much lower than average.

North China and Northeast China are the two main areas noted for renewable water use, which is relevant for the importance attached by the governments at all levels, water scarcity, high levels of socioeconomic development, long pipeline and other factors. Among these, the number of recycling plants in Beijing ranks fourth, but their production capacities and utilization rate are leading the country. Thus, the scale of individual recycling plants in Beijing is relatively large; as such, the operating costs can be reduced.

In 2010, the annual reclaimed water use in Beijing was approximately 680 million tons, accounting for $20 \%$ of the city's water supply. This use is projected to be over 1000 million tons in 2015 (Jin et al., 2014).

\section{Problems and challenges}

\subsection{Discharge standard and upgrading}

\subsubsection{Discharge standard}

The development of sewage discharge standards is a very important topic in water reclamation (Handcock and Knight, 1992; Heitmann et al., 2002, 2003; Li et al., 2012; Liao et al., 2015; Nash, 1988; Taylor and Frey, 2013; Zhu et al., 2013). Its value depends on several factors, including wastewater treatment technology, the concentrations of pollutants in the discharge, water environment and quality requirements of the reclaimed water, investment costs, water quality monitoring, and evaluation methods.

China's sewage treatment discharge standards have developed through several stages, from the "Integrated Wastewater Discharge Standard" (GB8978-1996) to the "Discharge Standard of Pollutants for Municipal Wastewater Treatment Plant" (GB 18918-2002) (Table 1). These standards have greatly improved sewage treatment in China, especially in the control of $\mathrm{N}$ and $\mathrm{P}$ pollutants, with the standard becoming increasingly stringent over the years ( $\mathrm{Li}$ et al., 2012; Liao et al., 2015; Zhu et al., 2013). Nonetheless, sewage treatment in China faces problems of insufficient and inefficient disposal, larger regional differences, inadequate capital being invested for disposal, harmonization of standards and overly stringent standards. These problems are bound to affect the normal operation of the sewage treatment industry, resulting in the standard changing blindly as well as resources being wasted (Frazier et al., 2013; Li et al., 2012; Liao et al., 2015; Zhu et al., 2013).

\subsubsection{Challenges for WWTP upgrading}

The Action Plan for Water Pollution Prevention and Control, which was put forward recently (Ministry of Environmental Protection, China, 2014), requires all WWTPs in areas where water has to be protected or is treated to meet the Grade I-A standard of effluent discharge. Some sewage treatment plants in Beijing are proposed to reach the IV standard of surface water. However, N2/3 of the existing WWTPs fall short of this requirement, which means that these treatment facilities have to be upgraded and investment in them increased.

Approximately $95.7 \%$ of the provinces had plants that enforced the Class 1 standard, and $\mathrm{N} 80 \%$ of all plants enforce the Class 1 standard. However, the reuse of wastewater is rare (Jin et al., 2014).

\subsubsection{Standards proposal}

National standards should be based on hazardous substances, such as toxic, persistent and dangerous biological bioaccumulative substances. With reference to toxic substances that are harmful to humans, a single standard should be established. Moreover, for other pollutants, discharge standards can be developed according to the actual situation in specific regions. The standards set by the regions should ensure that the water quality does not continually deteriorate, but rather, continue to improve. For the discharge of nitrogen and phosphorus from urban sewage treatment plants, the standard should be decentralized to each municipality or watershed.

Discharge standards should be established differently by functional national planning according to the quality of the receiving water and with guidance from the national standards for restricted development zones, and these standards can be slightly stringent. For the prohibited development zones, the standards should be the most stringent. If the sewage is to be used for irrigation, then there is no need to remove nitrogen and phosphorus, which helps to save processing costs (Frazier et al., 2013; Oliveira and von Sperling, 2008).

\subsection{Sludge disposal}

\subsubsection{Sludge composition}

Due to the tropic structure differences from developed countries and imperfect indoor sanitation facilities, some regions in China have failed to discharge sludge into the urban sewage pipe network (Yang et al., 2015a; Zeng et al., 2014). In addition, most of the sewage systems have a septic tank in the front, which has a great impact on the organic content of the sludge produced.

A survey of N 100 WWTPs of different sizes showed that high organic matter content of sludge (mostly $40-60 \%$ dry matter), high calorific value (10-15 MJ/kg, dry measurement) and high nitrogen and phosphorus content $(3-6 \% \mathrm{~N}, 1-2 \% \mathrm{P})$ are the main problems for urban

Table 1

Wastewater discharge standards in China.

\begin{tabular}{|c|c|c|c|c|c|c|}
\hline \multirow[t]{2}{*}{ Indicator } & \multicolumn{2}{|c|}{$\begin{array}{l}\text { Integrated Wastewater Discharge } \\
\text { Standard (GB8978-1996) }\end{array}$} & \multicolumn{3}{|c|}{$\begin{array}{l}\text { Discharge Standard of Pollutants for Municipal } \\
\text { Wastewater Treatment Plant (GB 18918-2002) }\end{array}$} & \multirow{2}{*}{$\begin{array}{l}\text { Environmental Quality Standards } \\
\text { for Surface Water (GB-3838-2002) } \\
\text { Grade IV }\end{array}$} \\
\hline & Grade I & Grade II & Grade I-A & Grade I-B & Grade II & \\
\hline SS & 20 & 30 & 10 & 20 & 30 & - \\
\hline COD & 60 & 120 & 50 & 60 & 100 & 30 \\
\hline BOD $_{5}$ & 20 & 30 & 10 & 20 & 30 & 6 \\
\hline $\mathrm{TN}$ & - & - & 15 & 20 & - & 1.5 \\
\hline TP & - & - & 0.5 & 1 & 3 & 0.3 (0.1 lake) \\
\hline $\mathrm{NH}_{3}-\mathrm{N}$ & 15 & 25 & $5(8)^{\star}$ & $8(15)^{*}$ & $25(30)^{\star}$ & 1.5 \\
\hline
\end{tabular}

* Lower than $12^{\circ} \mathrm{C}$ in the bracket. 
sludge management and disposal (Jiang et al., 2010; Li et al., 2013; Yan et al., 2012; Yang et al., 2015a; Zhang et al., 2009). Studies have also indicated that the proportion of organic matter in sludge in China is approximately $36.6 \%$, which is below the level of Jiangsu Province. The main reason for this is the extreme imbalance of the regional economy. Jiangsu Province is ranked first in China for GDP, and the cities with the highest sludge recycling rates are all within this province. Compared with developed countries, whose recycling rates are $70-80 \%$, there is a long way to go to improve the overall level of resource utilization.

The high water content is another obstacle that affects sludge treatment and disposal (Li et al., 2013; Yang et al., 2015a). The vast majority of dewatered sludge in China contains $80-85 \%$ moisture. Furthermore, the sludge is extremely malodorous and contains a large number of pathogens. High water content leads to a large amount of sludge production, which affects subsequent disposal (e.g., landfilling and incineration). By contrast, the moisture content of dewatered sludge is expected to be below $60 \%$, which is relevant to advanced technologies and, more importantly, to high energy consumption in the sludge dewatering stage.

In China, a special phenomenon takes place in some WWTPs, whereby wastewater is mixed with sludge of heavy metals, including $\mathrm{Cu}, \mathrm{Zn}$, $\mathrm{Cd}, \mathrm{Cr}$, and Ni, surpassing the set standard (Babel and del Mundo Dacera, 2006; Chen et al., 2005; Gu et al., 2013; Johnson et al., 1981; Pan, 2010; Tsakou et al., 2003; Wang et al., 2003; Weng et al., 2014; Yuan et al., 2015). In the sludge treatment process, over one-half of heavy metal elements is deposited in the sludge by way of adsorption by bacteria and mineral particles as well as co-precipitation with inorganic salts. Additionally, in built-up areas, the rain and sludge diversion rate is low, which affects the concentration of contaminants. This is a particularly important source for the transfer of heavy metals to the sludge. According to recent studies, the heavy metal contents in sludge vary widely in different cities and even countries (Azizi et al., 2013; Mattenberger et al., 2008; Phuengprasop et al., 2011; Vogel et al., 2013; Weng et al., 2014; Wu et al., 2015; Yuan et al., 2015). In most cases, the concentration of zinc is highest, followed by that of copper. Furthermore, the microbial species and quantities in the sludge are related to the lifestyle in the city, which tends to change over time.

\subsubsection{Sludge disposal standards}

According to the different approaches of sludge treatment and disposal, the Ministry of Housing and Urban-Rural Development and the Ministry of Environmental Protection have enacted more than ten national and industry standards on sludge land use, sludge landfilling, utilization as building materials, and sludge incineration, which includes landscaping, soil improvement, farming, mixed landfill, cement, brick, separate incineration and mixed refuse incineration(Table 2). However, there are many problems in the application process, and the requirements of the Standard for pollutant control in agricultural sludge (GB 4284-1984), enacted N30 years ago, has not been met.

The Discharge Standard of Pollutants for Municipal Wastewater Treatment Plant (GB 18918-2002), a more comprehensive standard that formulates a controlling standard for sludge dewatering, sludge stabilization and a limit for agricultural heavy metals and organic pollutants in sludge, does not meet the needs of actual sludge treatment and disposal. Compared with developed countries, Chinese sludge disposal standards lag behind. We acknowledge that the standard-setting system is incomplete system and that further coordination is needed between the different standards. In addition, the established standards are not periodic, and some transitional standards are particularly needed. Moreover, the 'one size fits all' model is not conducive for large-scale and decentralized sludge processing. In addition, while most established standards are focused on sludge, what is needed at present is a reliable system that involves the proposal procedures, specifications and technical guidelines to guide the rationalization and implementation of sludge treatment and disposal.

Overall, the primary task that urban WWTPs are confronted with is contaminants, followed by the reduction of sludge, stabilization, hazard reduction, and increased resource utilization. Urban sludge disposal technologies should be based on the requirements for disposal according to the standard for sludge quality and compared with other technologies, evaluating the actual local situation to decide the best engineering solutions.

\subsubsection{Trends of sludge disposal}

Based on the current situation of sludge treatment and disposal in Chinese WWTPs, sludge is the key to resource recycling in the wastewater treatment process. For low resource utilization in sludge treatment, resource recycling of the "contaminants" in sludge will be the focus of future development and research. Specifically, Anaerobic ammonium oxidation (Anammox) and Nitrogen fixation techniques will be important research directions.

\subsection{Energy consumption}

\subsubsection{Status of energy consumption}

As discussed in Section 3, AAO and oxidation ditch have been adopted in $\mathrm{N} 50 \%$ of the existing WWTPs. WWTPs with capacities

Table 2

Classification of sludge disposal and standards.

\begin{tabular}{|c|c|c|c|c|}
\hline \multirow[t]{2}{*}{ Classify } & \multirow[t]{2}{*}{ Scope } & \multirow{2}{*}{$\begin{array}{l}\text { Standards } \\
\text { Number }\end{array}$} & & \\
\hline & & & Name & Released units \\
\hline Sludge land use & $\begin{array}{l}\text { Landscaping } \\
\text { Soil improvement } \\
\text { Farm-oriented }\end{array}$ & $\begin{array}{l}\text { GB/T 23486-2009 } \\
\text { GJ/T 362-2011 } \\
\text { GB/T 24600-2009 } \\
\text { GB 4284-1984 } \\
\text { CJ/T 309-2009 }\end{array}$ & $\begin{array}{l}\text { Disposal of sludge from municipal wastewater treatment plant-Quality } \\
\text { of sludge used in gardens or parks } \\
\text { Disposal of sludge from municipal wastewater treatment plant-Quality } \\
\text { of sludge used in Woodland with argillaceous } \\
\text { Disposal of sludge from municipal wastewater treatment plant-Quality } \\
\text { of sludge used in Land improvement } \\
\text { Standard for pollutant control in agricultural sludge } \\
\text { Disposal of sludge from municipal wastewater treatment plant-Quality } \\
\text { of sludge for agricultural use }\end{array}$ & $\begin{array}{l}\text { MOHURD }^{\mathrm{a}} \\
\text { MOHURD }^{\mathrm{a}} \\
\text { MOHURD }^{\mathrm{a}} \\
\text { MEP }^{\mathrm{b}} \\
\text { MOHURD }^{\mathrm{a}}\end{array}$ \\
\hline Sludge landfill & Mixed landfill & GB/T 23485-2009 & $\begin{array}{l}\text { Disposal of sludge from municipal wastewater treatment plant- Mixed } \\
\text { landfill shale }\end{array}$ & MOHURD $^{\mathrm{a}}$ \\
\hline building materials & $\begin{array}{l}\text { Cement } \\
\text { Brick }\end{array}$ & $\begin{array}{l}\text { CJ/T 314-2009 } \\
\text { GB/T 25031-2010 }\end{array}$ & $\begin{array}{l}\text { Disposal of sludge from municipal wastewater treatment plant- Cement } \\
\text { clinker with argillaceous production } \\
\text { Disposal of sludge from municipal wastewater treatment plant- Brick } \\
\text { shale }\end{array}$ & $\begin{array}{l}\text { MOHURD }^{\mathrm{a}} \\
\text { MOHURD }^{\mathrm{a}}\end{array}$ \\
\hline Sludge incineration & $\begin{array}{l}\text { Separate incineration } \\
\text { Mixed with refuse incineration }\end{array}$ & $\begin{array}{l}\text { GB/T 24602-2009 } \\
\text { GB 18485-2001 }\end{array}$ & $\begin{array}{l}\text { Disposal of sludge from municipal wastewater treatment plant- Separate } \\
\text { incineration of sludge } \\
\text { Standard for pollution control of municipal solid waste incineration }\end{array}$ & $\begin{array}{l}\text { MOHURD }^{\mathrm{a}} \\
\text { MEP }^{\mathrm{b}}\end{array}$ \\
\hline
\end{tabular}

\footnotetext{
aOHURD:Ministry of Housing and Urban-Rural Development.
}

MEP:Ministry of Environmental Protection. 
b $10 \times 10^{4} \mathrm{~m}^{3} / \mathrm{d}$ constitute as high as $88.3 \%$ of the total number of WWTPs. In contrast, WWTPs with capacities of $1 \times 10^{4} \mathrm{~m}^{3} / \mathrm{d}-5 \times$ $10^{4} \mathrm{~m}^{3} / \mathrm{d}$ constitute $60 \%$.

As shown in Table 3, in addition to simple chemical and physicochemical processes, the energy consumption of the four commonly used technologies at the same scale of the WWTPs in descending order are: Traditional activated sludge N SBR N A2/O (A/O) N Oxidation ditch (Xu et al., 2014). In terms of the same type of technology, the most economical energy scale for traditional activated sludge is larger than $20 \times 10^{4} \mathrm{~m}^{3} / \mathrm{d}$. Similarly, the most economical scale for SBR is $1 \times 10^{4} \mathrm{~m}^{3} / \mathrm{d}-5 \times 10^{4} \mathrm{~m}^{3} / \mathrm{d}$, whereas that for A2/O is $10^{4} \mathrm{~m}^{3} / \mathrm{d}-50 \times 10^{4} \mathrm{~m}^{3} / \mathrm{d}$. For oxidation ditch, the most economical scale is $10 \times 10^{4} \mathrm{~m}^{3} / \mathrm{d}-20 \times 10^{4} \mathrm{~m}^{3} / \mathrm{d}$.

\subsubsection{Measures for reducing consumption and saving energy}

In general, electricity consumption constitutes the largest operating cost in Chinese WWTPs, which is followed by personnel cost, equipment depreciation, and chemical consumption (Huang et al., 2013).

There is a strong correlation between the energy consumption and scale of WWTPs. According to statistics, the biological treatment stage contributes $62.2 \%-71.1 \%$ of the total energy consumption, whereas the pretreatment and sludge treatment stages contribute $23.5 \%-25.1 \%$ and $4.1 \%-13.9 \%$, respectively. Furthermore, the majority of energy consumption in the biological treatment stage mainly occurs in the aeration system, while that in the pretreatment stage is mainly associated with the water pumps. In developed countries, such as the United States, the energy consumption of water and wastewater treatment is up to approximately $1 / 3$ of the total energy consumed by municipal public facilities and up to $3 \%$ of the total energy consumed. The annual electricity consumption is approximately 56 billion KW. N2/3 ofenergy consumption and associated costs are used in wastewater and sludge treatment.

Urban sewage treatment is an energy-intensive industry. The transport and treatment of domestic wastewater imposes a significant energy demand, consuming $3 \%$ of the electrical energy supply in the U.S.; values for other countries are 3-5\% (Foladori et al., 2015; Gil-Carrera et al., 2013; Huang et al., 2013; Mizuta and Shimada, 2010; Serralta et al., 2002; Skouterisl et al., 2014; Terrazas et al., 2010; Venkatesh and Brattebo, 2011). In 2010, municipal public facilities, including WWTPs, accounted for $1 \%$ of China's total energy consumption. As urban development improves and the rate of wastewater treatment increases, energy consumption in the urban sludge treatment plants will inevitably increase. Energy saving can be achieved by optimizing the design and layout of WWTPs, pumps, aeration equipment, sludge treatment equipment, and mixing equipment.

\subsection{Wastewater reclamation and reuse}

\subsubsection{Problems associated with reclaimed water use}

At present, China has not established an index system for urban sewage recycling. In the vast majority of urban WWTPs, the discharge is only required to meet a standard, without considering the size of the wastewater reuse. In addition, water distribution systems were not installed at the construction stage for most roads. For some roads, there was no provision for the laying of pipelines, which limits options for the reuse of water in large quantities and also results in redundant construction and superfluous investments.

Infrastructure construction lags behind. The collection and treatment of urban sewage is an important prerequisite for recycling urban wastewater. However, in China, sewage treatment facilities and related sewage pipe network construction lag behind the city development. Moreover, relevant policies and regulations are also lacking. Wastewater recycling in cities requires the protection of sound and comprehensive laws and unified management. It is evident that China's urban sewage recycling regulations are imperfect. Thus far, no law has been enacted by the NPC (National People's Congress) for the reuse of water or for encouraging the use of renewable water. The existing normative documents are mostly administrative laws and regulations, and the provisions are too general to regulate the development of the local renewable water industry.

Furthermore, the pricing mechanism is unreasonable. In China, the current water tariff is designed to compensate for the operating costs and to reduce subsidies, which does not reflect the value of water as a scarce resource. Price relationships between the various water uses are unscientific, which leads to slow progress in developing strategies to reuse water.

Moreover, the level of marketization and industrialization is low. At present, the investment channels for the construction of urban sewage treatment facilities derive mainly from government funding, directly resulting in ambiguous processes involving administration of government and enterprises, lack of energy in wastewater treatment and recycling companies, low investment efficiency, prevention of the growth of wastewater treatment market, restricting sewage treatment and discouraging the creation of a benign investment mechanism for recycling operations.

Awareness of the use of recycled water is also lacking. Currently, the vast majority of water users have doubts about recycled water. At the same time, awareness about reclaimed water is weak, hindering the widespread use of reclaimed water.

\subsubsection{Trends in water reclamation and reuse}

4.4.2.1. Disinfection technologies for recycled water. Disinfection is a necessary part of sewage recycling and is also key to ensuring the safety of reclaimed water from pathogenic organisms. However, in the practice of sewage treatment in China, it is common to find disinfection facilities not being utilized or being employed without supervision. The biological indicators of reclaimed water should be strictly monitored to protect the health and safety of recycled water. The disinfection methods commonly include chlorine, chlorine dioxide, ultraviolet, and

Table 3

Energy consumption statistics of 3095 WWTPs in China.

\begin{tabular}{|c|c|c|c|c|c|c|c|}
\hline \multirow[t]{2}{*}{ Scale $\left(10^{4} \mathrm{~m}^{3} / \mathrm{d}\right)$} & \multirow[t]{2}{*}{ Number } & \multirow{2}{*}{$\begin{array}{l}\text { Unit water power range }(\mathrm{kw} \cdot \mathrm{h} / \mathrm{t}) \\
\text { Chemical and physi-Chemical }\end{array}$} & & & & & \\
\hline & & & Oxidation ditch & $\mathrm{A} 2 / \mathrm{O}(\mathrm{A} / \mathrm{O})$ & Traditional activated sludge & SBR & Other \\
\hline$\geq 50$ & 15 & $\begin{array}{l}0.0253-0.145 \\
\text { (3) }\end{array}$ & / & $\begin{array}{l}0.130-0.514 \\
\text { (7) }\end{array}$ & $\begin{array}{l}0.131-0.270 \\
\text { (5) }\end{array}$ & / & / \\
\hline $20 \mathrm{~b} \mathrm{~S} \leq 50$ & 94 & $\begin{array}{l}0.108-0.268 \\
(2)\end{array}$ & $\begin{array}{l}0.177-0.411 \\
(11)\end{array}$ & $\begin{array}{l}0.138-0.439 \\
(48)\end{array}$ & $\begin{array}{l}0.114-0.373 \\
(10)\end{array}$ & $\begin{array}{l}0.144-0.585 \\
\text { (6) }\end{array}$ & $\begin{array}{l}0.144-0.476 \\
(17)\end{array}$ \\
\hline $10 \mathrm{~b} \mathrm{~S} \leq 20$ & 253 & $\begin{array}{l}0.201-0.313 \\
\text { (3) }\end{array}$ & $\begin{array}{l}0.117-0.444 \\
(56)\end{array}$ & $\begin{array}{l}0.122-0.574 \\
(118)\end{array}$ & $\begin{array}{l}0.226-0.569 \\
(20)\end{array}$ & $\begin{array}{l}0.156-0.417 \\
(19)\end{array}$ & $\begin{array}{l}0.113-0.470 \\
(37)\end{array}$ \\
\hline $5 \mathrm{~b} \mathrm{~S} \leq 10$ & 446 & $\begin{array}{l}0.148-0.386 \\
(10)\end{array}$ & $\begin{array}{l}0.135-0.822 \\
(125)\end{array}$ & $\begin{array}{l}0.106-0.682 \\
(141)\end{array}$ & $\begin{array}{l}0.123-0.584 \\
(38)\end{array}$ & $\begin{array}{l}0.122-0.630 \\
(55)\end{array}$ & $\begin{array}{l}0.0515-0.443 \\
(77)\end{array}$ \\
\hline $1 \mathrm{~b} S \leq 5$ & 1850 & $\begin{array}{l}0.0765-1.30 \\
(86)\end{array}$ & $\begin{array}{l}0.0573-1.225 \\
(551)\end{array}$ & $\begin{array}{l}0.115-1.42 \\
(403)\end{array}$ & $\begin{array}{l}0.096-0.765 \\
(180)\end{array}$ & $\begin{array}{l}0.0786-1.24 \\
(207)\end{array}$ & $\begin{array}{l}0.0520-1.54 \\
(423)\end{array}$ \\
\hline $\mathrm{S} \leq 1$ & 437 & $\begin{array}{l}0.0779-0.1031 \\
(63)\end{array}$ & $\begin{array}{l}0.134-2.12 \\
(77)\end{array}$ & $\begin{array}{l}0.091-2.28 \\
(57)\end{array}$ & $\begin{array}{l}0.0845-3.18 \\
(74)\end{array}$ & $\begin{array}{l}0.0886-1.61 \\
(24)\end{array}$ & $\begin{array}{l}0.0762-2.33 \\
(142)\end{array}$ \\
\hline
\end{tabular}


ozone disinfection among others. Although these methods can inactivate common pathogenic microorganisms, they have certain limitations. For example, chlorine disinfection is poor for Cryptosporidium and Giardia inactivation. Ultraviolet disinfection can effectively inactivate Cryptosporidium and Giardia, but the inactivated bacteria (pathogens) can be repaired under light (light resurrection) or dark (dark repair) conditions to regain activity and cause secondary health risks.

Of particular concern is that new pathogens have emerged in recent years. These include the predominantly high-risk pathogenic viruses, and this situation demands higher safety requirements when using recycled water. Therefore, the existing single disinfection technology is inadequate to address the high risk posed by these pathogenic microorganisms. The combination of different disinfection methods in recycled water treatment should be the focus of future developments, for which further research is required.

4.4.2.2. Technologies for controlling poisonous and harmful substances in recycled water. The existing water treatment technologies and processes mainly aim at controlling suspended solids (SS), chemical oxygen demand control (COD), color and other conventional pollution indices. However, for recycled water treatment, removing those conventional indicators cannot guarantee the quality and safety of the recycled water. In recent years, increasing attention has been paid to technologies for the removal of emerging pollutants, such as endocrine disrupting chemicals (EDCs), persistent pollutants (POPs), pharmaceuticals and personal care products (PPCPs) and the removal of particular hazardous substances. This has also become a controversial topic internationally. However, the composition of toxic and hazardous pollutants in water regeneration is very complex. As such, the evaluation and removal of certain toxic and hazardous chemicals cannot effectively protect the safety of reclaimed water. Therefore, technologies for the reduction of integrated biological toxicity (biological effects) of recycled water treatment are required.

4.4.2.3. Technologies for tertiary removal of nitrogen and phosphorus in recycled water. After secondary biological treatment, urban sewage still contains high concentrations of nitrogen, phosphorus and other plant nutrients. For example, according to the "Municipal Wastewater Treatment Plant Pollutant Emission Standards (GB18918-2002)," a sewage treatment plant has an "A" standard at total nitrogen and phosphorus concentrations of no $\mathrm{N} 15$ and $0.5 \mathrm{mg} / \mathrm{L}$, respectively. However, these concentrations are significantly higher than that required for eutrophication to occur. The discharge of recycled water containing high concentrations of nutrients to the urban environment and landscape can cause eutrophication, undermining ecological wellbeing. Therefore, tertiary removal of nitrogen and phosphorus is essential for controlling eutrophication, which can contribute to safeguarding recycled water use, especially the ecological wellbeing of the environment and landscapes.

4.4.2.4. Control technology for water quality degradation in the process of storage and transportation. Recycled water may still contain some organic matter and microorganisms (including pathogenic microorganisms) after tertiary treatment. Consequently, the possibility for water quality to deteriorate during storage cannot be overemphasized. More importantly, the deterioration of water quality during distribution and transportation through the pipeline network can threaten the safety of the reclaimed water. The concentrations of organic matter in renewable water (including assimilable organic carbon) are significantly higher than those in drinking water. On one hand, these organisms can serve as nutrients for microbial growth, whereas on the other hand, they speed up the reduction of chlorine in the water. Thus, their presence promotes the growth of microorganisms (including pathogenic microorganisms) in the process of storage and transportation. Therefore, just controlling the quality of the effluent water cannot sufficiently guarantee the water quality and safety at the terminus. As a result, a high degree of importance must be attached to developing technologies that can secure water quality during distribution and storage.
4.4.2.5. Technology of maintaining recycled water quality in environment and landscape use. Northern China faces severe water scarcity. Therefore, landscape and ecological water use do not necessarily consider a variety of factors, such as safety, economy and maneuverability. Landscape and ecological use account for a significant proportion of recycled water uses. Currently, Olympic Park in Beijing, Gaobeidian Lake, Kun Yu, South moat, the Longtan Lake and Taoranting Lake use recycled water as their water sources. In Tianjin, Qingdao, Hefei and other cities, reclaimed water has been gradually used to replenish the drying landscape rivers and lakes. The capacity of reclaimed water landscape use is constantly expanding. However, due to the limitations of the current quality standard for landscape water use, recycled water still contains high concentrations of nitrogen, phosphorus and other nutrients, including small amounts of toxic and hazardous pollutants. Because nitrogen, phosphorus and other nutrients cause a higher risk of eutrophication and the long-term accumulation of small amounts of toxic and hazardous pollutants has potential ecological risks, the short-term and long-term risk of using recycled water in landscape and ecological areas should be given more attention.

\subsubsection{Prospect of wastewater recycling}

Wastewater recycling is effective for solving water shortage problems. In the next 10 years, China's wastewater recycling sector will be nearly fully developed, and a huge market will have been created. The key element involved in wastewater recycling is water quality security. However, at present, China's renewable water management mechanisms and systems remain far from meeting the safety needs of reclaimed water. Meanwhile, sewage recycling technologies are encountering many challenges. Establishing and improving the water reuse security system and continuously developing advanced technologies for wastewater reclamation and water quality control should be the main focus for wastewater recycling in China.

The removal of toxic and hazardous substances and the reduction of biological toxicity must be the goal of future processing technologies. Furthermore, the tertiary removal of nitrogen and disinfection technologies aimed at "cooperative control" of high-risk pathogens and disinfection byproducts constitutes the main technologies required for wastewater treatment. For reclaimed water distribution, storage and use, guidelines and control technologies for water quality deterioration during the process of reuse are an important research direction.

\section{Conclusions}

Through the analysis of the current state of WWTPs in China, the following conclusions are drawn:

(1) By the end of 2013, 3508 WWTPs had been built in 31 provinces and cities in China, with a total treatment capacity of $1.48 \times 10^{8} \mathrm{t} / \mathrm{d}$, and the national average is approximately 0.12 $\left(10^{4} \mathrm{t} / \mathrm{d} \cdot 10^{4} \mathrm{P}\right)$. The uneven population distribution between China's East and West has resulted in very different economic development outcomes.

(2) The technologies mostly used in the WWTPs are AAO and oxidation ditch, which account for over 50\% of the existing WWTPs and $46 \%$ of the treated water.

(3) According to statistics, the removal efficiencies of $\mathrm{COD}$ and $\mathrm{NH}_{3}-\mathrm{N}$ are good in $656 \mathrm{WWTPs}$ in 70 cities. The overall average COD removal is over $88 \%$, with the regions betraying only small differences.

(4) Large differences exist between the operating loads applied in different WWTPs. The average operating loading rate is approximately $83 \%$. In the whole country, $52 \%$ of WWTPs operate at loadings of b $80 \%$, treating up to $40 \%$ of the generated wastewater.

(5) The implementation of discharge standards has been poor. Approximately 28\% of the WWTPs that achieved the Grade I-A Discharge Standard of Pollutants for Municipal Wastewater 
Treatment Plant (GB 18918-2002) were constructed after 2010.

(6) In terms of discharge standards and upgrading, sludge disposal, energy consumption, water reclamation and reuse, it is difficult for only one sewage discharge standard to meet the needs of different regional environmental administrations. The sludge treatment and recycling rate is only $25 \%$ Nearly $15 \%$ of wastewater is inefficiently treated. Approximately $60 \%$ of WWTPs have capacities of $1 \times 10^{4} \mathrm{~m}^{3} / \mathrm{d}-5 \times 10^{4} \mathrm{~m}^{3} / \mathrm{d}$. There is relatively high energy consumption for the small-scale processing and low utilization rate for recycled wastewater.

\section{Acknowledgements}

This study is supported by the National Natural Science Foundation of China (Grant No.51508447), the National High Technology Research and Development Program of China (Grant No.2011AA060903), Program for Innovative Research Team in Shaanxi (PIRT) (Grant No. 2013KCT-13), Major Science and Technology Program for Water Pollution Control and Treatment (Grant No.2013ZX07315-001), Soft Science Program from Ministry of Housing and Urban-Rural Development of China (Grant No.2011-k7-14). The collaboration between University of Technology Sydney (UTS) and Xi'an University of Architecture and Technology (XAUAT) is also very grateful.

\section{References}

Azizi, A.B., Lim, M.P., Noor, Z.M., Abdullah, N., 2013. Vermiremoval of heavy metal in sewage sludge by utilising Lumbricus rubellus. Ecotoxicol. Environ. Saf. 90, 13-20.

Babel, S., del Mundo Dacera, D., 2006. Heavy metal removal from contaminated sludge for land application: a review. Waste Manag. 9 (26), 988-1004.

Chen, Y.X., Hua, Y.M., Zhang, S.H., Tian, G.M., 2005. Transformation of heavy metal forms during sewage sludge bioleaching. J. Hazard. Mater. 1-3 (123), 196-202.

Feng, L., Luo, J., Chen, Y., 2015. Dilemma of sewage sludge treatment and disposal in China. Environ. Sci. Technol. 8 (49), 4781-4782.

Foladori, P., Vaccari, M., Vitali, F., 2015. Energy audit in small wastewater treatment plants: methodology, energy consumption indicators, and lessons learned. Water Sci. Technol. 6 (72), 1007-1015.

Frazier, M., Miller, A.W., Lee II, H., Reusser, D.A., 2013. Counting at low concentrations: the statistical challenges of verifying ballast water discharge standards. Ecol. Appl. 2 (23), 339-351.

Gil-Carrera, L., Escapa, A., Moreno, R., Moran, A., 2013. Reduced energy consumption during low strength domestic wastewater treatment in a semi-pilot tubular microbial electrolysis cell. J. Environ. Manag. 122, 1-7.

Gu, C., Bai, Y., Tao, T., Chen, G., Shan, Y., 2013. Effect of sewage sludge amendment on heavy metal uptake and yield of ryegrass seedling in a mudflat soil. J. Environ. Qual. 2 (42), 421-428.

Handcock, M., Knight, D., 1992. Improving discharge planning standards. Nurs. Stand. 21 (6), 38-40.

Heitmann, K.U., Schweiger, R., Dudeck, J., 2002. Discharge and referral data exchange using global standards-the SCIPHOX project in Germany. Stud. Health Technol. Inform. 90, 679-684.

Heitmann, K.U., Schweiger, R., Dudeck, J., 2003. Discharge and referral data exchange using global standards-the SCIPHOX project in Germany. Int. J. Med. Inform. 2-3 (70), 195-203.

Huang, X., Han, H., Qiao, J., 2013. Energy consumption model for wastewater treatment process control. Water Sci. Technol. 3 (67), 667-674.

Jiang, J., Du, X., Yang, S., 2010. Analysis of the combustion of sewage sludge-derived fuel by a thermogravimetric method in China. Waste Manag. 7 (30), 1407-1413.

Jin, L., Zhang, G., Tian, H., 2014. Current state of sewage treatment in China. Water Res. 66, 85-98.

Johnson, D.E., Kienholz, E.W., Baxter, J.C., Spangler, E., Ward, G.M., 1981. Heavy metal retention in tissues of cattle fed high cadmium sewage sludge. J. Anim. Sci. 1 (52), 108-114.

Li, W.W., Sheng, G.P., Zeng, R.J., Liu, X.W., Yu, H.Q., 2012. China's wastewater discharge standards in urbanization: evolution, challenges and implications. Environ. Sci. Pollut. Res. Int. 5 (19), 1422-1431.

Li, W., Shi, Y., Gao, L., Liu, J., Cai, Y., 2013. Occurrence, distribution and potential affecting factors of antibiotics in sewage sludge of wastewater treatment plants in China. Sci. Total Environ. 445-446, 306-313.

Liao, Z., Hu, T., Roker, S.A., 2015. An obstacle to China's WWTPs: the COD and BOD standards for discharge into municipal sewers. Environ. Sci. Pollut. Res. Int.

Liu, N., Shi, Y., Li, W., Xu, L., Cai, Y., 2014. Concentrations and distribution of synthetic musks and siloxanes in sewage sludge of wastewater treatment plants in China. Sci. Total Environ. 476-477, 65-72.
Mattenberger, H., Fraissler, G., Brunner, T., Herk, P., Hermann, L., Obernberger, I., 2008. Sewage sludge ash to phosphorus fertiliser: variables influencing heavy metal removal during thermochemical treatment. Waste Manag. 12 (28), 2709-2722.

Ministry of Environmental Protection, 2013. China Environmental Status Bulletin (in chinese).

Ministry of Environmental Protection, China, 2014. Action Plan for Water Pollution Prevention and Control.

Mizuta, K., Shimada, M., 2010. Benchmarking energy consumption in municipal wastewater treatment plants in Japan. Water Sci. Technol. 10 (62), 2256-2262.

Nash, T.B., 1988. What's new about the new discharge planning standards? Disch. Plann. Update 5 (8) $(1,11-13)$.

National Bureau of Statistics; Ministry of Environmental Protection, 2014r. China Urban Construction Statistics Yearbook (in Chinese).

Oliveira, S.C., von Sperling, M., 2008. Elements for setting up discharge standards in developing countries based on actual wastewater treatment plant performance. Water Sci. Technol. 10 (58), 2001-2008.

Pan, H., 2010. Effects of liquefaction time and temperature on heavy metal removal and distribution in liquefied CCA-treated wood sludge. Chemosphere 4 (80), 438-444.

Phuengprasop, T., Sittiwong, J., Unob, F., 2011. Removal of heavy metal ions by iron oxide coated sewage sludge. J. Hazard. Mater. 1 (186), 502-507.

Qu, Y.D., 2007. The application conceive of PIPP investment and financing mode on sewage treatment plant. Dalian University of Technology (in chinese).

Serralta, J., Ribes, J., Seco, A., Ferrer, J., 2002. A supervisory control system for optimising nitrogen removal and aeration energy consumption in wastewater treatment plants. Water Sci. Technol. 4-5 (45), 309-316.

Skouterisl, G., Arnot, T.C., Jraou, M., Feki, F., Sayadi, S., 2014. Modeling energy consumption in membrane bioreactors for wastewater treatment in North Africa. Water Environ. Res. 3 (86), 232-244.

Taylor, J.A., Frey, L.T., 2013. The need for industry and occupation standards in hospital discharge data. J. Occup. Environ. Med. 5 (55), 495-499.

Terrazas, E., Vazquez, A., Briones, R., Lazaro, I., Rodriguez, I., 2010. EC treatment for reuse of tissue paper wastewater: aspects that affect energy consumption. J. Hazard. Mater. 1-3 (181), 809-816.

Tsakou, A., Roulia, M., Christodoulakis, N.S., 2003. Growth parameters and heavy metal accumulation in poplar tree cultures (Populus euramericana) utilizing water and sludge from a sewage treatment plant. Bull. Environ. Contam. Toxicol. 2 (71), 330-337.

Venkatesh, G., Brattebo, H., 2011. Environmental impact analysis of chemicals and energy consumption in wastewater treatment plants: case study of Oslo, Norway. Water Sci. Technol. 5 (63), 1018-1031.

Vogel, C., Exner, R.M., Adam, C., 2013. Heavy metal removal from sewage sludge ash by thermochemical treatment with polyvinylchloride. Environ. Sci. Technol. 1 (47), 563-567.

Wang, C.J., 2013. The analysis and study on the problem of equipment renewal of urban sewage treatment. Kunming University of Science and Technology (in chinese).

Wang, J., Huang, C.P., Allen, H.E., 2003. Modeling heavy metal uptake by sludge particulates in the presence of dissolved organic matter. Water Res. 20 (37), 4835-4842.

Weng, H.X., Ma, X.W., Fu, F.X., Zhang, J.J., Liu, Z., Tian, L.X., et al., 2014. Transformation of heavy metal speciation during sludge drying: mechanistic insights. J. Hazard. Mater. 265, 96-103.

Wu, Q., Duan, G., Cui, Y., Sun, J., 2015. Removal of heavy metal species from industrial sludge with the aid of biodegradable iminodisuccinic acid as the chelating ligand. Environ. Sci. Pollut. Res. Int. 2 (22), 1144-1150.

Xu, S.W., Liu, F., Bai, Y., Li, Y., Gao, Y., 2014. Research and consideration of energy consumption standard quota of the wastewater unit in Beijing. Water \& Wastewater Engineering Vol. 40(11), pp. 109-111 (in chinese).

Yan, H., Zhang, C.J., Zhou, Q., Chen, L., Meng, X.Z., 2012. Short- and long-chain perfluorinated acids in sewage sludge from Shanghai, China. Chemosphere 11 (88), 1300-1305.

Yang, Y., Wang, Y.M., Wang, Q., Zhang, X., Yang, Y., Sun, C., Xiao, Q.C., 2011. Analysis on current municipal wastewater teeatment plants operation in China. Water \& Wastewater Engineering Vol. 37(8), pp. 35-39 (in chinese).

Yang, Y., Xu, H., Yin, J.F., 2012. Analysis on resource utilization of sewage sludge in the sewage treatment plants of China. South-To-North Water Transfers and Water Science \& Technoogy Vol. 10(5), pp. 114-118 (in chinese).

Yang, G., Zhang, G., Wang, H., 2015a. Current state of sludge production, management, treatment and disposal in China. Water Res. 78, 60-73.

Yuan, X., Leng, L., Huang, H., Chen, X., Wang, H., Xiao, Z., et al., 2015. Speciation and environmental risk assessment of heavy metal in bio-oil from liquefaction/pyrolysis of sewage sludge. Chemosphere 120, 645-652.

Zeng, L., Wang, T., Ruan, T., Liu, Q., Wang, Y., Jiang, G., 2012. Levels and distribution patterns of short chain chlorinated paraffins in sewage sludge of wastewater treatment plants in China. Environ. Pollut. 1 (160), 88-94.

Zeng, L., Yang, R., Zhang, Q., Zhang, H., Xiao, K., Zhang, H., et al., 2014. Current levels and composition profiles of emerging halogenated flame retardants and dehalogenated products in sewage sludge from municipal wastewater treatment plants in China. Environ. Sci. Technol. 21 (48), 12586-12594.

Zhang, T., Yu, G., Wang, B., Fiedler, H., Huang, J., Deng, S., 2009. Bioanalytical characterization of dioxin-like activity in sewage sludge from Beijing, China. Chemosphere 5 (75), 649-653.

Zhu, L., Liu, B., Wang, F., Bi, J., 2013. Raising discharge standards leads to environmental problem shifting in China. Water Sci. Technol. 12 (68), 2605-2612. 